\title{
THE PERFORMANCE OF FRIESIAN STEERS GRAZING 'GRASSLANDS ROA' TALL FESCUE PASTURES ON PEAT SOILS IN THE WAIKATO
}

\author{
G. J. Goold and F. C. C. HupKens van Der Elst \\ Soil and P/ant Research Station, \\ Ruakura Agricultural Research Centre, Hamilton
}

\begin{abstract}
Legume-based pastures of perennial ryegrass ('Grasslands Ruanui + Nui') and 'Grasslands Roa' tall fescue were established on semidevelop\&d peat soils near Hamilton in autumn 1975. Pastures were grazed with yearling Friesian steers at equal stocking rates from August until March during the years 1976 to 1979.

Roa tall fescue swards substantially outyielded those of perennial ryegrass in January, February and March with an overall total yield advantage of some $21 \%$. As a result, in most months, steers grazing Roa were offered approximately $15 \%$ more DM, which was utilized with similar efficiency to ryegrass $(67 \%$ tall fescue and $69 \%$ ryegrass)'.

Steer liveweight gains per head and per hectare were $10 \%$ higher on Roa tall fescue pastures, with average daily growth rates being $0.74 \mathrm{~kg} / \mathrm{head}$ and the 5 -year mean total LWG/ha being $970 \mathrm{~kg}$ from the tall fescue pasture.
\end{abstract}

\section{INTRODUCTION}

VAN DER ELST (1979) concluded that the lack of persistence of perennial ryegrass (Lolium perenne L.) pastures on newly dedevoped Waikato peat soils was a major limitation to increased dairy farm production. Frequently the soils are poorly consolidated and drained, resulting in waterlogged pastures which develop shallow rooting systems unable to withstand the effects of summer drought. Under these conditions pasture productivity can markedly decline and mortality of desirable species can be severe.

Small plot mowing trials at Moanatuatua Peat Research Area have shown that improved tall fescue cultivars (Festuca arundi. nacea Schreb.) develop a deeper, stronger root system than ryegrass cultivars and remain more productive under conditions of severe moisture stress. Further, it was observed that Friesian steers readily grazed strips of 'Grasslands Roa' tall fescue in preference to those of S170 tall fescue or 'Grasslands Ruanui' ryegrass during the drier periods of the year. The breeding and selection of 
Roa, which was formerly known as 'Grasslands 4710 ' tall fescue. has been described by Anderson (1975), and the cultivar is expected to be commercially available in 1980 .

Although there have been many favourable reports on the performance of improved tall fescue cultivars throughout New Zealand (Al10 and Southon, 1967; Watkin, 1975; Allen and Cullen, 1975; Sheath et al., 1976), the species is frequently condemned through its association with the wild, unpalatable weed type so common in wet, swampy areas to which it is naturally adapted.

A grazing experiment was therefore begun in 1976 to determine whether or not the superiority of Roa tall fescue over perennial ryegrass suggested in mowing trials could be sustained under grazing and the advantage realized in terms of animal liveweight gain.

\section{EXPERIMENTAL}

Following a greenfeed maize crop on semi-developed peat soils at the Moanatuatua Peat Research Area near Ohaupo, pastures of perennial ryegrass and Roa tall fescue were established in autumn 1975. The ryegrass treatment was sown as an equal mixture of 'Grasslands Ruanui' and Nui at $29 \mathrm{~kg} / \mathrm{ha}$, and Roa tall fescue at $37 \mathrm{~kg} / \mathrm{ha}$, Both pastures were seeded with $3.4 \mathrm{~kg} / \mathrm{ha}$ of 'Grasslands Huia' white clover (Trifolium repens L.) . Additional pastures of ryegrass and 'Grasslands G 14' phalaris (P. aquatica L.) were also established in autumn 1975, the ryegrass pastures being undersown with paspalum (P. dilatatum Poir.) in the spring. The phalaris treatment failed to persist and was subsequently resown to Ellet's ryegrass, an uncertified cultivar. Each pasture was established with dressings of lime $(1000 \mathrm{~kg} / \mathrm{ha})$ and fertilizer (480 kg/ha of $15 \% \mathrm{~K}$ superphosphate) and maintained with spring and autumn applications of fertilizer, Although the experimental design was four replications of four pasture types, only the data comparing perennial ryegrass and Roa tall fescue pastures will be presented.

All pastures were uniformly managed to encourage maximum grass growth until the grazing experiment commenced in the spring of 1976. Thereafter yearling Friesian steers were placed in separate mobs, at equal stocking rates on each pasture type, and rotationally grazed around each of the four replicate paddocks until the following autumn, when low pasture growth rates necessitated their removal from the trial area. Overall stocking rates were increased and decreased according to the available feed supply and expected pasture growth rates, although stock numbers were al- 
ways the same in each treatment mob. The length of the grazing rotation was also altered according to pasture growth rates, being in the order of 20 to 30 days in the spring and decreasing from 20 to 14 days in the autumn when available feed supplies had diminished. The steers received regular anthelmintic drenching and were weighed unfasted at 9 a.m. at approximately 14-day intervals. The liveweight gain data were not statistically analysed, since high between-paddock variability precluded the use of the individual animal as an experimental unit.

Pasture production measurements consisted of pre- and postgrazing quadrats cut to ground level from each paddock during the grazing rotation. Growth during the grazing period was estimated from the mean growth rates of the. adjacent recovery periods. Monthly herbage yields were calculated from the growth rates dver the appropriate periods. Botanical composition of pregrazing yields was determined by herbage dissection of selected cuts in the spring and autumn of each year.

The experiment ran for 3 years from 1976 to 1979, commencing September 6, August 11 and August 12, and concluding March 22, February 27 and March 30, respectively, in those years.

\section{RESULTS}

\section{PASTURE PRODUCTION}

The mean monthly herbage yields of the perennial ryegrass and tall fescue swards over the 3-year experiment are shown in Fig. 1. The advantage in herbage yield to Roa tall fescue pastures over the months of January-February-March is clearly evident and resulted in a total yield advantage of some $21 \%$ (Table 1 ). The tall fescue pastures continued to grow at a rate in excess of $60 \mathrm{~kg}$ $\mathrm{DM} /$ ha/day after December, whereas ryegrass pasture growth rates declined. The difference between the two pasture types was significant $(P<0.05)$ in February. The superior growth of Roa pastures resulted in higher pre-grazing yields (Table 1), and hence higher allowances for the steers grazing this treatment. The ryegrass pastures also showed greater variation in pre- and postgrazing yields throughout the seasons, while the tall fescue pastures had somewhat higher, minimum pre-grdzing yields. Since utilization of the tall fescue and ryegrass swards was similar (at $67 \%$ and $69 \%$, respectively), higher post-grazing yields were recorded from the fescue pastures. 


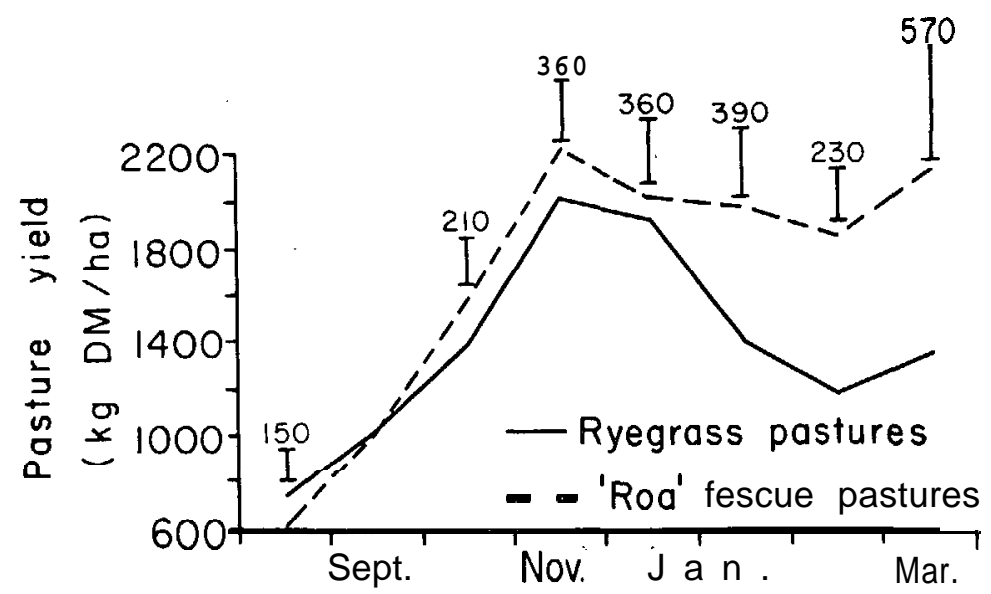

FIg. 1: Total herbage yields, Monnatuatua (mean of 3 years 1976-79).

\section{Botanical Composition}

The composition of the ryegrass and tall fescue pastures is shown in Fig. 2. Although the content of sown grass was higher in Roa pastures initially, in subsequent seasons and years there appeared to be little difference between the treatments in this component.

There also appeared to be little decline in the proportion of sown grass in either treatment over the experimental period, with

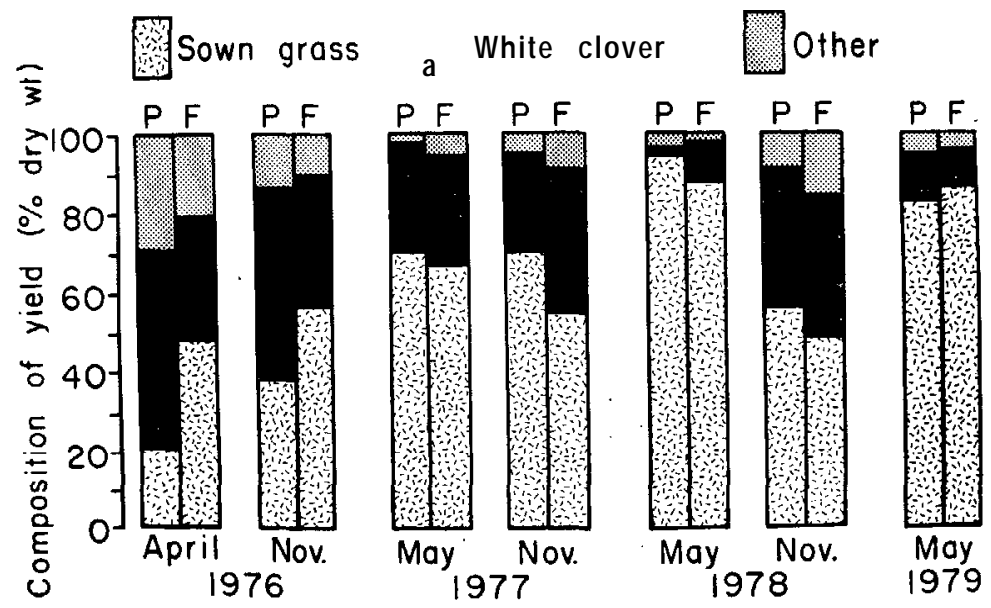

FIG. 2: Botanical composition of Roa fescue (F) and perennial ryegrass $(P)$ pastures. 
TABLE 1: EFFECT OF HERBAGE SPECIES ON PASTURE AND ANIMAL PRODUCTION PARAMETERS (MEAN OF 3 YEARS 1976-9)

\begin{tabular}{|c|c|c|c|c|c|c|c|}
\hline $\begin{array}{l}\text { Production } \\
\text { Parameters }\end{array}$ & Perennial & $\begin{array}{r}\text { Pasture } \\
\text { Ryegrass }\end{array}$ & $\begin{array}{r}\text { Species } \\
\text { Roa }\end{array}$ & Fescue' & $\begin{array}{l}\text { S.E. of } \\
\text { Diff. }\end{array}$ & $\begin{array}{l}\text { Significance } \\
\text { L e v e I }\end{array}$ & $\begin{array}{l}\text { Advantage } \\
\text { to R oa }\end{array}$ \\
\hline $\begin{array}{l}\text { Herbage production } \\
\text { (t DM/ha) }\end{array}$ & mean & & mean & & & & \\
\hline Total & 10.3 & $(13.3-8.5)^{\prime}$ & 12.5 & $(16.7-8.9)$ & 0.8 & $5 \%$ & $21 \%$ \\
\hline Pre-graze & 1.93 & $(0.5-4.4)^{2}$ & 2.22 & $(0.9-3.8)$ & 0.09 & $5 \%$ & $15 \%$ \\
\hline Post-graze & 0.60 & $(0.2-1.7)$ & 0.73 & $(0.3-1.6)$ & 0.06 & $10 \%$ & $22 \%$ \\
\hline$\%$ utilization & 69 & & 67 & & & & $-2 \%$ \\
\hline LWG/steer (kg) & 157 & - & 173 & - & n.a.* & n.a. & $10 \%$ \\
\hline LWG/ha (kg) & a77 & - & 973 & - & n.a. & n.a. & $10 \%$ \\
\hline
\end{tabular}


"other species" forming only a very minor proportion of herbage yields. Clover content was higher in ryegrass pastures during the spring and autumn of 1976, although thereafter the main effect on the clover component was seasonal, with clover yields being reduced in the autumn compared with spring, on both pasture types.

\section{Antmal Production}

The mean monthly liveweight gains of steers grazing ryegrass and Roa tall fescue pastures are shown in Fig. 3, and total yields in Table 1. The steers in each treatment were stocked at an average rate of $5.6 /$ ha over the total grazing period of each year, with maximum stocking rates being attained in late OctoberNovember (approximately 8 steers/ha).

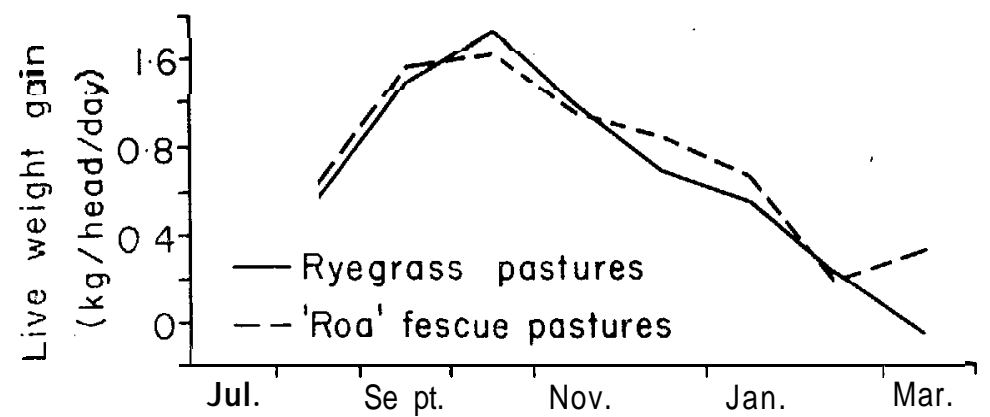

Fig. 3: Daily grow th rate of Friesian steers (mean of 3 years 19X-79).

The average daily liveweight gains showed that the Friesian steers grew faster on Roa pastures in 5 out of the 8 months, in each experimental year. The advantage was particularly marked over the months of December, January and March, when presumably DM intake became more limiting for the steers grazing ryegrass pastures. At the end of each experimental year, the steers grazing Roa pastures were on average $16 \mathrm{~kg}(10 \%)$ heavier per head and yielded approximately $100 \mathrm{~kg}$ of additional liveweight gain per hectare.

\section{DISCUSSION}

Reports on grazing evaluations of improved tall fescue cultivars in New Zealand are scarce. Wilson (1975) reported that production from dairy cows offered ad libitum quantities of pure S170 and G4710 tall fescues was similar to that produced from pure pastures of 'Grasslands Ariki' ryegrass, Lolium perenne X ( $L$. perenne $\mathbf{x}$ L. multiflorum.L.), althoughliveweight gains of dairy heifers were lower on the tall fescue pastures. However, when 
clover was present in significant amounts, the animal production from the various pasture types was similar.

The present experiment has confirmed the view that satisfactory stock performance can be achieved from Roa tall fescue and white clover pastures. Furthermore, there was no evidence of stock ill health or metabolic disorder recorded on the tall fescue pastures.

The ability of improved tall fescue cultivars to produce substantial quantities of DM over a wide range of environmental conditions has been noted by Cowan (1956). The environmental conditions on peat soils at Moanatuatua are such that extreme differences in soil moisture status can rapidly occur each year, and under these conditions Roa tall fescue pastures have a clear advantage over perennial ryegrass. Although ryegrass persisted in terms of plant survival throughout the experimental period, the vigour and growth of this species was severely restricted by moisture stress over the late summer months. Improved water table control on newly developed peat soils would improve the relative performance of perennial ryegrass pastures, although Roa tall fescue should continue to be the superior species through its ability to produce green herbage during dry spells, as shown in -this experiment.

In general, the liveweight gains of the Friesian steers reflected the pasture growth rates and the DM on offer throughout each season. Since pasture growth rates were generally higher on the tall fescue pasture and since stocking rates were always uniform between treatments, the steers grazing the tall fescue had more DM on offer, and hence the grazing pressures were lower on these pastures on most occasions. Further, since the steers utilized both pasture types with similar efficiencies $(69 \%$ utilization of ryegrass and $67 \%$ of tall fescue), the post-grazing yields were higher on the Roa tall fescue pasture. The higher stubble yield, together with superior root growth of Roa tall fescue, resulted in greater physical support of the grazing animal during wet periods, which was an important practical consideration.

The daily liveweight gain of steers grazing Roa tall fescue during the period August-March was, on average, $0.74 \mathrm{~kg} / \mathrm{head}$, which can be considered a satisfactory performance level. The steers grazing perennial ryegrass pastures also made satisfactory liveweight gains until pasture growth rates fell to low levels after December, and although there was always some DM on offer late in the season, it was of low nutritive value, being predominantly dead, stalky material. In contrast, the steers grazing Roa pasture 
always had some green herbage on offer to them over the dry summer-autumn period.

The wider use of this improved tall fescue grass cultivar, in similar environments, should result in increased pastoral dairy farm production.

\section{ACKNOWLEDGEMENTS}

The authors express their gratitude to J. Corby and W. Hamilton for their technical field work, and to C. Dyson for the statistical advice on data handling in the preparation of this paper.

\section{REFERENCES}

Allen, R. B.; Cullen, N. A., 197.5. Proc. N.Z. Grassld Ass., 36 (2): 209-13. Allo, A. V.; Southon, T., 1967. Proc. N.Z. Grassld Ass., 28: 128-34.

Anderson, L. C., 1975. Proc. N.Z. Grassld Ass., 36 (2): 198-9.

Cowan, J. R., 1956. Advances in Agronomy, 8: 283-320.

Sheath, G. W.; Galletly, W. S.; Greenwood, P., 1976. Proc. N.z. Grassld Ass., 38 (1) : 140-50

van der Elst, F. C. C., 1979. Proc, Ruakura Fmrs' Cont. (in press).

Watkin, B. R., 1975. Proc. N.z. Grassld Ass., 36 (2): 180-90.

Wilson, G. F., 1975. Proc. N.Z. Grassld Ass., 36 (2): 200-8. 